\title{
EL SIMBOLISMO DE LAS LETRAS Y DEL LENGUAJE SEGÚN IBN 'ARABI
}

Pierre Lory (La Sorbona)

Recibido el 20/03/2016. Aceptado el 18/06/2016.

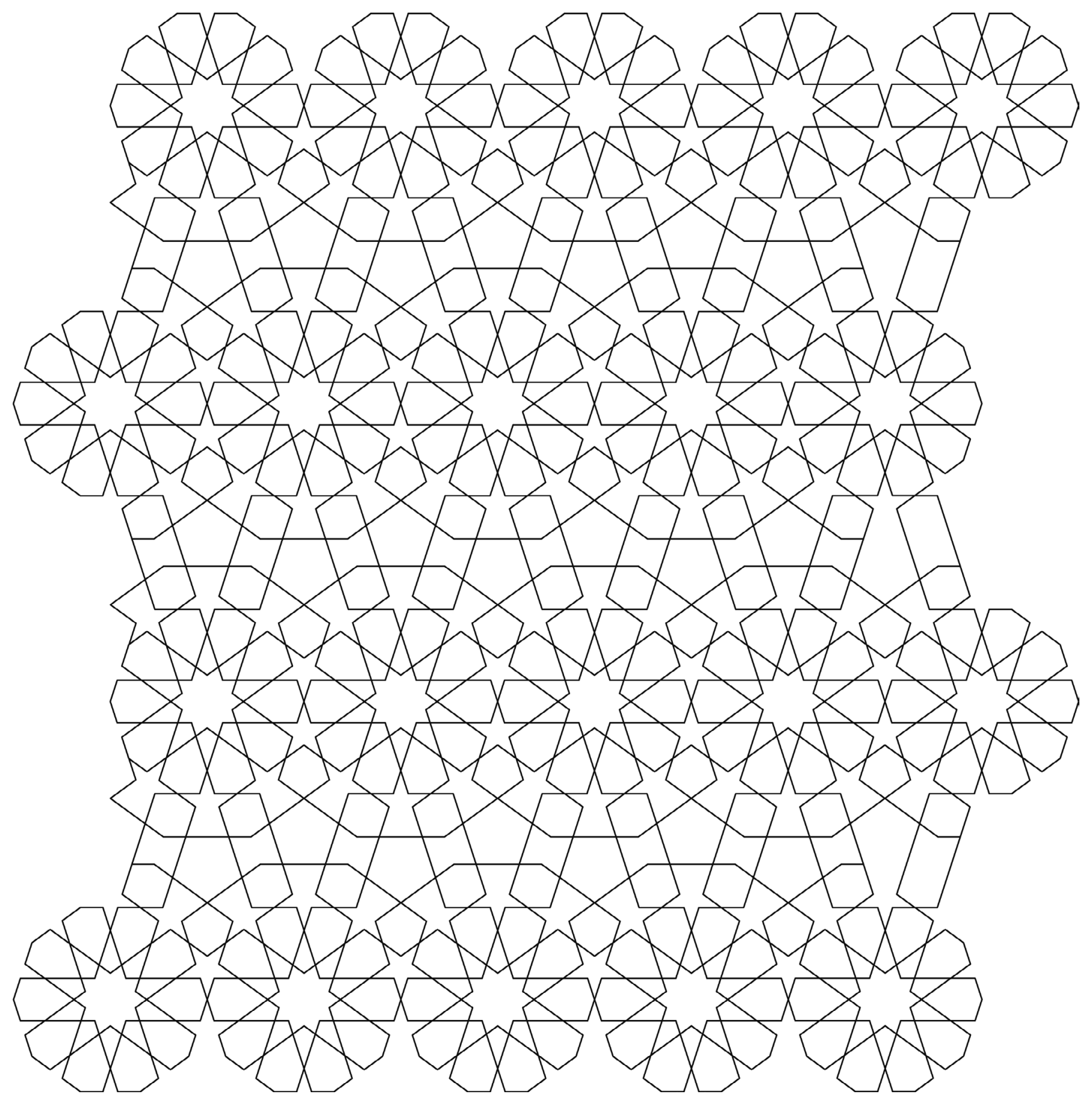


El título de este texto podría parecer bastante ambicioso a los lectores familiarizados con el pensamiento de Ibn al-'Arabī. La concepción del lenguaje y la ciencia mística de las letras, que es su corolario, son en efecto una de las partes centrales de la obra del Maestro Máximo (al-Šayh al-Akbar), y a la vez la más sintética y abstrusa. Este tema requeriría de hecho varios volúmenes de análisis. Mi propósito no es pues tratar este inmenso tema de manera exhaustiva, sino simplemente exponer algunos aspectos y también aportar algunas modestas aclaraciones. Antes que nada, examinaré la cuestión del lenguaje en su relación con los orígenes, después con relación a la revelación (coránica) y, finalmente, con respecto a la función espiritual del hombre.

La visión del origen del mundo que se desprende de los escritos de Ibn al-'Arabī está estrechamente vinculada a su concepción del lenguaje. El acto de creación para Dios no es distinto de su acto de palabra: una solidaridad orgánica une estos dos modos de ser. Dios instaura en el ser una multitud indefinida de creaturas por medio de una palabra, y estas creaturas se vuelven vocablos del inmenso discurso divino que es el universo. Se trata en este caso de una ontología en el sentido más estricto, ya que el ser se identifica con el logos según expresión de Henry Corbin ${ }^{1}$. Recordemos brevemente los principales términos de la cosmogonía akbarí.

\section{LA LETRA DE LOS ORÍGENES}

No me entretendré en este tema que es muy conocido y que ha sido analizado y expuesto en detalles en obras de síntesis (especialmente, W. Chittick, 1989, pp. 33 y ss.). Recordemos que, según Ibn al-'Arabī, la esencia divina Una, Solitaria e Impenetrable crea los seres a partir de la nube ('amā'). En este nivel, los seres solo existen en el estado de puros posibles, como simples pensamientos en el espíritu de Dios, en el estado de "esencias permanentes" (a yyann țābita). ¿Qué es lo que hará salir fuera de esta nube los seres desde este estado de posibilidad hasta el ser manifestado? Es la palabra divina llamando las cosas al ser. La instancia organizadora de los seres manifestados es designada por Ibn al-'Arabī como los "Nombres divinos". Por "Nombres", no hay que entender aquí los términos precisos en el lenguaje humano (por ejemplo: "Misericordioso" o "Todopoderoso") que leemos o pronunciamos. Estos son más bien "los nombre de estos nombres" (asma $\bar{a}^{\prime}$ al-asm $\bar{a}$ ), las diversas modalidades gracias a los cuales Dios impulsa y organiza el ser en el universo. Estos Nombres aportan a la vez la energía necesaria para la salida al ser, y la estructura general imponiendo orden y armonía a los seres entre sí2

Individualmente, el nombre de cada ser corresponde a la intención divina que le hizo existir, a la relación que une la Esencia a cada existencia concreta particular. Ibn al-'Arabī considera al Nombre como Padre, y a la esencia permanente como "madre" de cada ser".

1 Véase P. Lory, La science des lettres en Islam, p. 56.

2 FM III, 441.

3 FM I, 138 ss. 
Este Nombre es la raíz de su acto de ser particular, su "Señor" al que tendrá que servir y seguir en el transcurso de su itinerario terrenal. Su destino particular consiste en realizar de esta forma las virtualidades contenidas en su esencia. "A toda realidad en este mundo corresponde un Nombre a que le es propio y que es su Señor". Este punto es esencial, según señala William Chittick:

"It must be concluded (...) that the divine names are the single most important concept to be found in Ibn al-'Arabī's works. Everything, divine or cosmic, is related back to them. Neither the Divine Essence nor the most insignificant creature in the cosmos can be understood without reference to them".

Cada ser en su acontecer constituye una letra en la composición del gran discurso cósmico. El pasaje de la letra como entidad virtual a aquella producida en los mundos manifestados tiene lugar bajo la acción de la rotación de las esferas ${ }^{6}$. Está explícitamente puesto en correspondencia con un proceso de emisión de la palabra, y esta "fonación divina" no es aquí una simple expresión alegórica. Hay homología constante entre creación divina y palabra humana. Dios crea por medio de un "soplo divino" llamado "hálito de misericordia" - nafas al-Rahmān-que sostiene continuamente la existencia del universo. Es esta expiración la que hace posible la "articulación" de las palabras divinas: "Las esencias de las palabras divina, que son veinte ocho (= número de las letras del alfabeto árabe) y están dotadas de aspectos múltiples, del Soplo de Misericordia, que es la Nube donde nuestro Señor se alzaba en el momento en el que creó el mundo. La Nube es homóloga al soplo humano, y la manifestación del mundo en el vacío en los diversos grados del ser es semejante al hálito humano que surge del corazón, difundiéndose a través de la boca y produciendo letras a su paso por los puntos de articulación. Las letras se asemejan a la manifestación del mundo a partir de la Nube que es el hálito de Dios Verdadero y Misericordioso propagándose en los grados determinados de una extensión virtual, no física, es decir del vacío que la creación viene a llenar ${ }^{7 ’}$. Esta homología entre creación y palabra es dinámica, ya que la creación es transitoria y no permanente, a la manera de un discurso que desarrolla frase por frase.

Desde esta perspectiva, entendemos mejor el desarrollo sobre las letras expuesto por Ibn al-'Arabī especialmente en el segundo capítulo de al-Futūhāt al-makkiyya, muy claramente presentado y parcialmente traducido por Denis Gril en el volumen Les Illuminations de La Mecque. El "Maestro Máximo" nos proporciona allí una profusión de tablas de correspondencias entre las letras y los niveles de existencia y de acción del cosmos que no siempre coinciden los unos con los otros. El lenguaje desempeña ahí la función de una suerte de álgebra cósmica. "La ciencia de las letras podría así definirse como una metalingüística y una metafísica enunciando los principios de la ciencia del

4 FM I, 99.

5 W. Chittick, The Sufi Path of Knowledge, 1989, 10.

6 FM (al-Futūhāt al-makkiyya) I, 52; M. Chodkiewicz et al., Illuminations de La Mecque, pp. 387, 439 y ss.

7 FM II, 395. 
lenguaje y del mundo físico", según escribe D. Gril ${ }^{8}$. Las mismas letras pueden ser empleadas para ilustrar procesos completamente distintos - de la misma forma que las cifras pueden aparecer en operaciones indefinidamente variadas. No existe una "ciencia de las letras" en un sentido en el que las letras serían el objeto de un saber específico; son las letras las que gracias a sus cargas semánticas y simbólicas dan acceso a una multiplicidad de saberes esotéricos. En efecto, "cada nombre tiene dos formas. Una de ellas nos es propio y procede de nuestros soplos y de las letras que juntamos: es por medio de (estos Nombres) que lo invocamos, son los nombres de los nombres divinos los cuales revisten como mantos. Por la forma de estos nombres, nos damos cuenta de los Nombres divinos. Las formas de éstos últimos se encuentran junto al Muy Misericordioso en tanto que es hablante y dotado de palabra. Tras estas formas, existen sentidos ( $\left.m a{ }^{(} \bar{a} n \vec{\imath}\right)$ que son como espíritus para ellas. Las formas de estos Nombres divinos por medio de los cuales Dios se designa a sí mismo en su discurso (= el Corán) tienen su existencia en el Hálito del Todo Misericordioso" ${ }^{\text {. }}$

Dicho esto, ¿qué podríamos hacer nosotros con estos planteamientos doctrinales? ¿En qué sentido podrían aportar claves a los creyentes para ayudarles en su crecimiento espiritual y su comprensión de su propio destino? Una primera respuesta ha de buscarse en la parte del verbo divino que es accesible al hombre - la palabra coránica.

\section{APLIGAGIONES A LA EXÉGESIS}

¿Cómo operar la unión entre el discurso divino cósmico y la palabra coránica? Ibn al-`Arabī nos aporta, mediante alusiones (ǐ̌ăāat) un cierto número de ejemplos de esta ciencia mística de las letras. Una "metafísica de la gramática" esta esbozada en la segunda sección del segundo capítulo de Futūhāt $t^{10}$. A lo largo del capítulo 198, meditaciones sobre la emisión de las dos letras $h \bar{a}^{\prime}$ y wāw se exponen ampliamente ${ }^{11}$. Ibn al-'Arabī nos proporciona igualmente algunos comentarios a continuación sobre el valor esotérico de ciertas letras. Así, por ejemplo, sobre las "letras aisladas"; o, la relación entre las letras alif $\mathrm{y} l \bar{a} m^{12}$.

Así pues, si las especulaciones sobre la significación espiritual de las letras son tan significativas en las escrituras de Ibn al-'Arabī, hasta el punto de que aparecen como una gran introducción en las Iluminaciones de La Meca, es porque desempeñan una función operativa en el proceso de transformación espiritual que es, en definitiva, el objeto final de toda la obra del Šayh al-Akbar -y no son una simple elaboración doctrinal especulativa. Cada ser humano es, ontológicamente, un verbo divino; en este sentido, la develación del sentido esotérico de un término, de una aleya coránica, puede conducir al

8 Illuminations, 410.

9 FM II , 396-397.

10 FM I, 84 ss.; Illuminations, 402 ss.

11 FM II , 390; Illuminations, 408 ss., 481.

12 FM I, 51 ss.; Illuminations, 393-8; y FM I, 75-77; Illuminations, 475-480. 
sufí a comprender un aspecto de su propia dimensión esotérica. Esto es particularmente verdadero en lo que concierne al texto coránico. El Corán, como verbo divino integrador que contiene potencialmente toda la Sabiduría universal, es el homólogo del ser humano. El hombre es, en efecto, un microcosmo que contiene en sí mismo el conjunto de las formas manifestadas en el universo. Dios creó el conjunto de lo que existe según una forma perfecta, total, el primer ser existenciado llamado en ocasiones "Realidad Muhammadí" o "Hombre Universal”. Se constata así que el Corán y el Hombre Universal designan en definitiva la misma sabiduría divina totalizadora. "El Hombre total según la realidad esencial es el Corán incomparable revelado desde la presencia de sí mismo hacia la Presencia de su Existenciador (...). En el cielo más cercano, se tornó "distinción” (furqān) y descendió bajo formas fragmentadas, según las realidades divinas, porque su autoridad se ejerce de diversas maneras, y debido al cual el Hombre se fragmenta igualmente (...). El Corán descendido es la verdad, según Dios lo denominó. Toda verdad inmediata conlleva una verdad última, y la verdad definitiva del Corán, es el Hombre, escribió Ibn al-'Arabīi' ${ }^{13}$.

Ya que la estructura humana es homóloga a la del verbo de Dios, el objetivo del sufí será conformarse en la medida de lo posible a este verbo divino. Se le invita a tornarse Corán y volviéndose palabra divina, se conforma igualmente a la figura del Hombre perfecto, realizando así su propia perfección individual, el Nombre que le es propio. Se entiende de ello que la ciencia esotérica del Corán, y en particular la de las letras que lo componen, no es un asunto de simple especulación deductiva o inductivo $^{14}$ : implica al gnóstico en su propio proceso de transformación personal. Esta concepción de la realidad humano-verbal del individuo explica la el énfasis otorgado por la espiritualidad islámica a todos los ritos que incluyen la recitación ritual de la palabra (recitación del Corán, [formas diversas del $\left.\left.\underline{d i k r}^{15}\right]\right)$. Permite también entender la distancia tomada respecto a la magia literal, cuya eficacia reconocía Ibn al-'Arabī, previniendo sin embargo de los peligros que podría implicar. Esta concepción se abre también a una verdadera filosofía del ser humano como sujeto parlante.

Porque la recitación del Corán no es la única exégesis abierta a los creyentes. Si el lenguaje nos constituye, nos organiza y nos atraviesa, nosotros podemos igualmente leer y experimentar la verdad que se expresa a cada instante en nuestra propia persona. Y nuestro propio lenguaje humano puede entonces traducir en verdad lo que somos. Pero esta traducción no podrá en modo alguno formularse por el lenguaje usual, profano, adecuado solamente para describir la dimensión terrestre, pero no la dimensión "vertical” presente en cada ser. Ésta pasará necesariamente por el medio de metáforas, de poesía y más generalmente, en forma de paradojas. Son estas paradojas inspiradas que los sufies de los primeros siglos designaban con el término šath $h^{16}$. Se entendía que estos šath-s eran proferidos por ser preferidos en estado de éxtasis, en un momento en que el místico había perdido el control de su

13 Isfār, 1994, 22-23.

14 FM I, 57.

15 Acción de Mencionar a Dios como un acto de adoración.

16 Término que pertenece al sufismo y que se refiere a un estado extático en una danza espiritual. 
propio discurso, lo cual excusaba la desmesura de su propósito. Pero entre cientos de estas palabras que la tradición sufí nos ha transmitido, la mayoría han sido visiblemente pronunciados de manera deliberada y se inscriben con claridad en el marco de una enseñanza espiritual. Abū Yazīd, citado en el Kitāb al-Luma' de Abū Naṣr al-Sarrāğ, afirma: "Una vez, Dios me arrebató, me llevó ante él y me dijo: ¡O Abū Yazīd, mis creaturas querrían verte! Yo dije: Embelléceme con tu unicidad (wahdāniyya), revísteme de tu yoidad (anāniyya), elévame hasta tu unitud (ahadiyya), con el fin de que tus creaturas digan cuando me vean: ¡nosotros te vemos! Y que sea a Ti (a quien ellos ven), iy que yo no esté!” O en otro dicho: "Al comienzo de mi viaje hacia su unicidad, me volví un pájaro cuyo cuerpo estaba hecho de unidad y cuyas dos alas estaban hechas de perpetuidad (daymūma). No paré de volar durante diez años en el aire de la cualidad (kayfyya) para llegar a un aire parecido cien millones de veces. Continué volando sin parar hasta que logré acceder a la explanada de la pre-eternidad; donde vi el árbol de la unidad [Sarrāğ: "Después describió su tierra, su base, sus ramajes y sus frutas, y dijo]: consideré entonces (esto) y supe que todo ello es un engaño"17. El lector se da cuenta aquí de que Abū Yazīd traduce una experiencia indecible en el lenguaje usual y da lugar a un nuevo manejo de este lenguaje, de esencia poética y formulación paradoxal, cuya audacia nos evoca por momentos la inmediatez de los koans del budismo zen.

Con respecto a esta cuestión de la paradoja y del šath, Ibn 'Arabī es a la vez prudente y preciso. Denuncia los šaṭh-s con severidad, considerándolos como dislates del lenguaje, marcados por una ostentación censurable desde una óptica espiritual, que podrían confundir al común de los creyentes. Pero, por otra parte, él no los ve como palabras fundamentalmente falsas. Es el peligro social de una mala comprensión de la parte de los no sufies lo que él denuncia. Él mismo comentará numerosos šaṭ̣-s de sus ilustres antecesores, integrando este fenómeno en su propia visión doctrinal. Así, a título de ejemplo, nos aporta un comentario copioso a la respuesta que dio Abū Yazīd Baṣtāmī cuando se le preguntó cómo se encontraba cierta mañana: "Ni mañana ni noche; la mañana y la noche pertenecen a los que están caracterizados por ellas, ¡y yo no tengo cualidades que me caractericen!" 18 Redactó también explicaciones contextualizadas de los šaṭ̣-s "teopáticos” atribuidos a Abū Yazīd, como "iyo soy Dios!” o "¡soy el Glorioso!”19.

Más aún, él mismo utilizará la paradoja de una manera completamente paralela a sus antecesores que fueron Abū Yazīd, Hallāğ o Šiblī. Entre los enunciados más frecuentes citemos los versos que aparecen en la introducción de Futūhă $t^{20}$ :

"El señor es verdad (haqq) y el servidor es verdad * iplazca al cielo que yo sepa quien está sumiso a la obligación legal!

17 V. pp. 461-467.

18 FM II, 646 ss.

19 FM I, 272 y $618 ; I I, 479 ; I V, 57$ у 90.

20Al-Futūhāt al-makkiyya, la obra magna de Ibn al-'Arabī. 
Si tú dices: es el servidor, el servidor esta sin vida *. Si tú dices: es el Señor, ¿de dónde le viene la obligación?”21

Y este otro verso tan adaptado a nuestro propósito sobre la "logomorfosis" del hombre:

"Soy el Corán y las siete redobladas; * el espíritu del espíritu, no el espíritu de los receptáculos.

Mi corazón reside al lado de Aquel que yo conozco * y que contemplo, mientras os hablo" ${ }^{22}$.

La postura de Ibn 'Arabī con respecto a los šath-s es bastante diferente de la de otros sufíes más extáticos, como Abū Yazīd y Rūzbihān. Estos últimos mantienen la tensión entre el vocabulario normal del mundo mortal, y el lenguaje de quien ha percibido la eternidad y para quien el tiempo y el espacio han cambiado definitivamente. El šath es para ellos la marca de una ruptura mental -salto o giro según las imágenes- que no cabe representarse. Ibn al-'Arabī, sin embargo, busca integrar las dos dimensiones del lenguaje -terrestre y eternizado- en una estructura doctrinal y exegética fluida, matizada, sin fallos ni rupturas.

\section{EL HOMBRE MEDIADOR}

El hombre creyente y monoteísta se encuentra en una situación delicada: se le requiere hablar de Dios, usar palabras, expresiones, que derivan del mundo material y social, y que pueden parecer inadaptadas al objeto de la metafísica. Si Dios es inmaterial, más allá de todo cuerpo y concepto, ¿cómo hablar de Él y describirlo? La teología musulmana tendrá que combatir este problema del antropomorfismo del lenguaje. Por supuesto, el Corán aporta a los hombres palabras, Nombres ("el Misericordioso", "El que perdona", por ejemplo) que permiten hablar de Dios y hablarle en la liturgia. Pero, ¿se podría ir más allá y usar la totalidad de la lengua para mantener el lazo entre Dios y la creatura a la cual Él se dirige? Los hanbalíes lo niegan: el creyente puede reproducir el texto coránico, pero no puede añadir ninguna noción que no pertenezca al Corán, ni siquiera por derivación lingüística o analógica.

Con Ibn al-'Arabī, ya lo hemos visto, no se deja encerrar en este tipo de aporías. Para él, el lenguaje no es unívoco y su uso no se limita a las posibilidades de la sintaxis o del diccionario; posee una dimensión vertical que se remonta hasta el origen de las cosas. Puede expresar la experiencia de lo divino con paradojas sin anular su coherencia, que remite a la harmonía misma de la creación. Permite al hombre nombrar las cosas conectándolas a los Nombres divinos que son sus raíces, en 
resumen, desempeñan la función de mediador universal con que fue investido que Adam desde los orígenes (Corán 2: 31 - 33). Por medio de la meditación íntima sobre la dimensión esotérica de las letras, el sufí puede en efecto relacionar letras, poner letras y nombres a todas estas cosas que se asemejan al macrocosmos, y puede incluso, por medio de este arte, tener dominio sobre él. Se aplica así a entender las frases de este lenguaje universal que anima la creación, que lo traviesa así como a todos los seres del universo; de dónde la noción del "lenguaje de los pájaros", o bien, la de la comprensión del mineral ${ }^{23}$. La superioridad del lenguaje humano con respecto a los otros lenguajes del mundo es análoga a la superioridad del hombre sobre otras criaturas. Del mismo modo que el hombre es un microcosmo en el cual se refleja el universo, asimismo, el lenguaje humano aporta la clave de todo lo que puede decirse o murmurarse bajo los nueve cielos. En este nivel, el lenguaje humano se vuelve como un retorno hacia el origen del Verbo creador instaura y organiza el ser. Desde esta perspectiva, se entiende mejor la visión que Ibn 'Arabī relata de su unión nupcial con las letras del alfabeto: "Me encontraba de noche en Ramadán del año 597 h., cuando me vi (en sueño) uniéndome carnalmente con todas las estrellas del cielo sin excepción, todo ello con un inmenso placer. Cuando terminé, las letras me fueron presentadas y me uní a todas ellas, tanto separadamente como en composición" ${ }^{24}$. Unirse físicamente a las letras del alfabeto equivale a identificarse con el acto divino creador el mismo, a volverse uno de estos hombres perfectos cuya voluntad individual se vuelve una simple prolongación de la voluntad divina.

Como conclusión hemos evocado arriba la doctrina visionaria de Mugīra ibn Sa $\mathbf{1} \bar{d}$ sobre la palabra como cuerpo de Dios. La figura del "Maestro Máximo" Ibn 'Arabī presenta un total contraste con la de Mugīra. Este último era un inspirado de ámbito popular, de condición humilde ${ }^{25}$, que se asoció a los movimientos de revuelta contra la opresión del califato de Damasco, y murió condenado de una violenta muerte. Ibn al-'Arabī sin embargo, venía de una gran familia de letrados andalusíes de origen árabe. Nacido en 1165, cinco siglos después de Mugīra, vivió en una época donde la doctrina musulmana había, desde hacía mucho tiempo, alcanzado su madurez. Se benefició de una sólida educación tanto profana como espiritual, se encontró desde la adolescencia con grandes figuras del derecho y la mística en al-Andalus y el Magreb. Su obra y su luz personal le proporcionaron bastante rápido un gran prestigio y una larga reputación en el conjunto del mundo musulmán. Tras sus numerosos viajes en occidente musulmán y luego a partir de 1201, en oriente, donde se instaló definitivamente, fue acogido con gran consideración no solo en los ámbitos sufies, sino también entre los aristócratas militares y los príncipes. Las pocas manifestaciones de hostilidad hacia él que tuvieron lugar fueron todas reducidas y sin continuidad alguna. No buscaba hacer un papel político o nada por el estilo, pero llegó a ser el maestro poco cuestionado de un principado espiritual que reunía en un solo corazón a miles de musulmanes fervientes. Uno de los aspectos más fundamentales de la

23 Illuminations, 52.

24 Kitäb al-bä, 11.

25 Se refiere a la clase social y cultural de la familia de Mugīra. 
elaboración doctrinal de Ibn al-'Arabī reside en su obra metafísica. Busca en ello, con desarrollos que presentan desde múltiples perspectivas un pensamiento sumamente rico en matices, exponer la procesión de un mundo indefinidamente múltiple manifestado a partir de la Esencia divina, fuente indescriptible de todo, perfectamente una, más allá de cualquier numeración. No hay lugar aquí para evocar los términos de esta teodicea que Henry Corbin diferenciaba de una emanación "fuera" de Dios. Y para discernir en ella manifestaciones de intensidad y de complejidad crecientes "en el interior" de Él; nosotros preferimos aquí remitirá las principales obras que están consagradas a ello. Lo importante aquí es señalar que la primera manifestación de la Esencia divina, aquella que los filósofos llaman a menudo el Intelecto Universal, está identificada en Ibn al-`Arabī con la forma humana primordial, la "Realidad muhammadí" (haqīqa muhammadiyya). Es esta Realidad muhammadí la que porta en ella las simientes de todos los seres, las "esencias inmutables” de todo lo que será. Que la constitución humana sea precisamente la forma de Dios, aquella que Dios concibió como resumen y modelo de todos los seres de la creación, es sugerido, observa Ibn 'Arabī, por un cierto número de tradiciones, como aquella que afirma que "Dios creó Adam según Su imagen". Esta forma sintética se encuentra manifestada en todo ser humano, pero en diversos grados de perfección. Es por supuesto más completa en el santo (walt) que en las personas ordinarias. El profeta Muhammad representa la perfección en acto de la forma más completa que haya conocido nunca la humanidad; es el Hombre Perfecto, el insān kāmil. Es en este sentido que el primer arquetipo de todos los seres se denomina Realidad muhammadí, y que un hadiz afirma: "yo era profeta cuando Adam aún estaba entre el agua y el barro".

Ahora bien, esta realidad primordial, este germen de todos los seres, está igualmente identificado con el Corán; no con el Corán materialmente presente en la tierra, sino con la "Madre del Libro", este arquetipo celestial guardado por los ángeles que contiene la ciencia del todo lo que es y será hasta el fin de los tiempos. Esto supone entonces que entre la estructura humana y la del Libro existe una completa homología. Ibn 'Arabī indica además explícitamente que el Hombre Perfecto y el Corán son "hermanos". Se apoya en varios hadices, como aquel en el que Muhammad manifiesta que ha recibido "la totalidad de las plabras" (ğawāmi`al-kalim); o también sobre esta palabra de 'Ā'iša atestiguando que "la naturaleza (de Muhammad) era el Corán".

Existe entonces necesariamente una relación muy estrecha que enlaza el cuerpo humano y el lenguaje; pero ello es por su puesto extremadamente complejo de expresar e incluso de concebir. Una clave importante puede sin embargo encontrarse a nuestro parecer, en el segundo capítulo de la obra maestra de Ibn al-'Arabī, al-Futūhāt al-makkiyya. Este texto a menudo desconcertante es una exposición de diversos temas de la ciencia simbólica de las letras del alfabeto árabe; las letras se presentan en él como cifras de diversas dimensiones de los mundos creados, de los cuales son a la vez el origen ontológico y la expresión simbólica más inmediata.

Una sección de este capítulo presenta las letras como una comunidad dotada de su jerarquía espiritual y de su Ley, pues las letras son ángeles jerárquicamente ordenados. El lazo real entre la forma 
humana y la estructura del lenguaje aparece bajo una nueva luz cuando se considera en términos de angelología: el cuerpo de la Realidad muhammadí, así como el texto de la Madre del Libro, es un pleroma angélico que difunde su propia armonía hasta los grados inferiores de la existencia.

Al término de estas breves anotaciones, se constata las dimensiones propiamente cosméticas que toma la noción del "libro" en la metafísica sufi. Ahora bien, estaríamos equivocados si pensáramos que nos encontramos aquí en presencia de abstractas especulaciones, herencia de algunos místicos aislados. La práctica musulmana más humilde está toda impregnada de la conciencia de esta dimensión sagrada del Corán. Un ejemplo concreto sería éste: a la hora del rezo ritual realizado cinco veces al día, el fiel debe recitar varios versículos coránicos - la primera sura, la Fätiha, y luego otro fragmento a elegir. Este rezo ritual incluye varias condiciones sin las cuales no sería válido: condiciones higiénicas, de pureza ritual sobre todo. Los contactos impuros, sugieren varios hadices ${ }^{26}$, alejar a los ángeles. Estos últimos están de hecho presentes durante la realización de esta liturgia personal del creyente; más aún, están misteriosamente asociados a ella, ya que su ausencia vaciaría el rito de su valor comunitario. Se entenderá mejor esta colaboración si vemos que no solo los ángeles rezan con las personas, sino que ellos mismos son las suras, los versículos, las letras mismas del texto coránico recitado por el orante. Recitar versículos es convocar por el hecho mismo la presencia de las entidades angélicas de cada palabra.

Asimismo, por la proclamación del texto sagrado, los devotos creyentes permiten la irrigación de este mundo terrestre por una constante y benéfica presencia angélica; con más razón en el caso de los sufies comprometidos con la vía mística. Estos, por medio de sus prácticas y de su transparencia interior, viven una progresiva transmutación individual. Estos santos, de los cuales se afirma que "el Corán está ligado a su carne y a su sangre”, según la expresión del místico egipcio D̄ū l-Nūn (siglo IX d. C.) se vuelven en cierto sentido Libro, es decir, se integran progresivamente a este pleroma angélico que constituye, como hemos visto, la naturaleza del Hombre Perfecto. Descubrimos aquí una visión del cuerpo, de su nobleza, de su necesidad en el proceso de transformación espiritual del hombre, que se sitúa en las antípodas de lo que propone la civilización actual en general. El organismo físico se vuelve como la matriz de una forma celeste, la manifestación del aspecto de un Corán oculto, el lugar donde manifiesta la sabiduría y la belleza divinas. Cabe recordar que a través de la experiencia de la danza un coreógrafo como M. Béjart ha descubierto la espiritualidad musulmana. Esta exaltación en la danza, que fue representada con un talento y una autenticidad sin igual por Ğalāl al-Dīn Rūmī, ¿no es también uno de los grandes mensajes que el sufismo podría aportar al siglo XX? En un mundo marcado por la inquietud y la tristeza tanto en Occidente como en Oriente, ¿podría asimismo recordar la dicha más elemental de cualquier impulso místico, simplemente - la dicha del ser?

Traducción del francés de Imad Boussif.

26 Comunicaciones orales, dichos y conjunto de actos y palabras del profeta Muhammad. 